\section{Results of laboratory diagnosis of rabies in herbivores (cattle and horses): a retrospective study}

\author{
Resultados do diagnóstico laboratorial de raiva em herbívoros \\ (bovinos e equinos): estudo retrospectivo
}

\author{
Noelle de Castro Barrosa', Hélio Langoni²*, Cassiano Victória², Benedito Donizete Menozziª \\ Karine Bott Mantovan', Giulia Soares Latosinski' \& Sâmea Fernandes Joaquim ${ }^{4}$ \\ 'Veterinarians, Residents in Zoonosis and Public Health. Departamento de Higiene Veterinária e Saúde Pública - DHVSP, \\ Universidade Estadual Paulista "uúlio de Mesquita Filho" - UNESP, Botucatu, SP, Brasil \\ Veterinarians, PhDs. Departamento de Higiene Veterinária e Saúde Pública - DHVSP, Faculdade de Medicina Veterinária e \\ Zootecnia - FMVZ, Universidade Estadual Paulista "Júlio de Mesquita Filho" - UNESP, Botucatu, SP, Brasil \\ ${ }^{3}$ Biologist, PhD student. Departamento de Higiene Veterinária e Saúde Pública - DHVSP, Faculdade de Medicina Veterinária e \\ Zootecnia - FMVZ, Universidade Estadual Paulista "Júlio de Mesquita Filho" - UNESP, Botucatu, SP, Brasil \\ ${ }^{4}$ Veterinary, PhD student. Departamento de Higiene Veterinária e Saúde Pública - DHVSP, Faculdade de Medicina Veterinária e \\ Zootecnia - FMVZ, Universidade Estadual Paulista "Júlio de Mesquita Filho" - UNESP, Botucatu, SP, Brasil
}

\begin{abstract}
Rabies is a zoonosis of extreme importance to public health. Specifically in herbivores it causes economic losses, considering its lethality. The diagnosis provides information to describe the epidemiology of the disease in the regional study. For this purpose, a survey of Central Nervous System (CNS) materials, received for diagnosis in the Center-West region of the State of São Paulo, by the Zoonosis Diagnostic Service (SDZ), Faculdade de Medicina Veterinária e Zootecnia (FMVZ) - UNESP-Botucatu-SP. In the period from 2001 to 2015 , a total of 643 samples were analyzed, being 489 (76.05\%) of the bovine species, with 68 (13.9\%) positive samples and 154 (23.95\%) of the equine species with 17 (11.3\%) positive. For the analyzed bovine samples, sensitivity and specificity values of the fluorescent antibody test (FAT) were 88.24 and $99.52 \%$ respectively and for equines, 47.06 and $100.0 \%$. The frequency of samples received by species, month, and year and the results of the diagnostic tests recommended by the World Health Organization (WHO), fluorescent antibody test (FAT) and the mouse inoculation test (MIT), were analysed.
\end{abstract}

Keywords: rabies, herbivores, diagnosis, surveillance.

\section{Resumo}

A raiva é uma zoonose de extrema importância para a saúde pública. Especificamente em herbívoros, causa perdas econômicas, considerando sua letalidade. O diagnóstico fornece informações para descrever a epidemiologia da doença no estudo regional. Para tanto, foi realizado um levantamento dos materiais do Sistema Nervoso Central (SNC), recebido para diagnóstico na região Centro-Oeste do Estado de São Paulo, pelo Serviço de Diagnóstico de Zoonoses (SDZ), Faculdade de Medicina Veterinária e Zootecnia (FMVZ) - UNESP - Botucatu -SP. No período de 2001 a 2015, foram analisadas 643 amostras, sendo 489 (76,05\%) da espécie bovina, com 68 (13,9\%) amostras positivas e 154 (23,95\%) da espécie equina com 17 (11,3\%) positivo. Para as amostras de bovinos analisadas, os valores de sensibilidade e especificidade do teste de anticorpos fluorescentes (FAT) foram 88,24 e 99,52\%, respectivamente, e para os equinos, 47,06 e100,0\%. Foram analisadas a frequência de amostras recebidas por espécie, mês e ano e os resultados dos testes diagnósticos recomendados pela Organização Mundial da Saúde(OMS), teste de anticorpos fluorescentes (FAT) e teste de inoculação em camundongos (MIT).

Palavras-chave: raiva, herbívoros, diagnóstico, vigilância.

\section{Introduction}

Rabies is a zoonosis characterized by acute encephalitis, caused by an RNA virus of the Mononegavirales order, Rhabdoviridae family. It mainly affects mammals, generating economic losses and constituting a severe public health problem (Lima et al., 2005; Kotait et al., 2009). Advancements have been obtained with control programs; however, rabies remains endemic in the Americas due to the presence of wild and domestic reservoirs (Wada et al., 2011). In the rural
How to cite: Barrosa, N. C., Langoni, H., Victória, C., Menozzi, B. D., Mantovan, K. B., Latosinski, G. S., \& Joaquim, S. F. (2018). Results of laboratory diagnosis of rabies in herbivores (cattle and horses): a retrospective study. Brazilian Journal of Veterinary Medicine, 40, e49218. doi: 10.29374/2527-2179.bjvm049218

\section{Financial support: None}

Conflict of interests: No conflict of interests declared concerning the publication of this article.

Received: December 11, 2017

Accepted: July 23, 2018.

The study was carried out at Laboratório de Diagnóstico de Zoonoses do Serviço de Diagnóstico de Zoonoses - SDZ, Faculdade de Medicina Veterinária e Zootecnia - FMVZ, Universidade Estadual Paulista "Júlio de Mesquita Filho" - UNESP, Botucatu, SP, Brasil.

\section{*Correspondence}

Hélio Langoni

Departamento de Higiene Veterinária e Saúde Pública - DHVSP, Faculdade de Medicina Veterinária e Zootecnia - FMVZ, Universidade Estadual Paulista "Júlio de Mesquita Filho" UNESP.

Rua Professor Doutor Walter Mauricio Correa, s/n, Unesp campus de Botucatu, CEP 18618-681 - Botucatu (SP), Brasil E-mail: hlangoni@fmvz.unesp.br

Copyright Barrosa et al. This is an Open Access article distributed under the terms of the Creative Commons Attribution Non-Commercial License which permits unrestricted non-commercial use, distribution, and reproduction in any medium provided the original work is properly cited. 
cycle of this disease, the vampire bat (Desmodus rotundus) is considered an important transmitter of the rabies virus (Kanitz et al., 2014).

In cattle and horses, its main clinical manifestation is the paralytic form, with paralysis of the hind limbs (Brasil, 2009). The Rabies Diagnosis Laboratory of the Zoonosis Diagnosis Service (SDZ), School of Veterinary Medicine and Animal Science (FMVZ), São Paulo State University (Unesp), Botucatu Campus, São Paulo State(SP), Brazil, is one of the labs accredited by the Rabies Diagnosis Laboratory Network of the Secretariat of Health Surveillance(SVS), Brazilian Ministry of Health (MS), for the diagnosis of this disease and has received samples from different cities in São Paulo State, effectively contributing to the rabies control program in this State, similarly to other labs of this Network.

Rabies diagnosis in horses requires attention since the distribution of viral particles in the CNS is not uniform (Keane \& Little,1987). The first pathogenic studies of rabies in this species reported two cases of natural infection, showing no Negri bodies in brain fragments and viral isolation only in the region of pons and medulla, which suggests the use of different brain fragments for the diagnosis of rabies in this species (Silva et al., 1974).

Sending brain samples for diagnosis favors the epidemiological study of this disease and the possible viral isolation for genetic and epidemiologic characterization (Queiroz et al., 2009). The aim of the present study was to evaluate rabies casuistry in suspected rabid cattle and horses, from 2001 to 2015, based on the databank of SDZ-FMVZ-Unesp, Botucatu Campus, SP, Brazil.

\section{Material and methods}

The analysis was done by collecting data of laboratory tests performed at SDZ-FMVZ-Unesp, Botucatu Campus, SP, Brazil, from 2001 to 2015, which were selected according to the animal species and origin. The CNS materials were from 134 municipalities, most of which belonged to the central-west region of São Paulo State, totaling 643 samples.

The techniques adopted for rabies diagnosis were those recommended by WHO: fluorescent antibody test (FAT) (Dean et al., 1996), for viral antigen detection, which used anti-rabies conjugate provided by Pasteur Institute at São Paulo, and mouse inoculation test (MIT), conducted according to the protocol described by Koprowski (1996), which consists in intrabrain inoculation of CNS suspension into 21-day-old Swiss Webster mice subjected to daily observation for 30 days; during this period, notes on their general state were taken. For diagnostic confirmation of the bioassay, every time an animal had clinical sign of the disease, its CNS was subjected to a new FAT (Robardet et al., 2011).

Statistical analysis was done with the software BioEstat 5.3 (Ayres et al., 2007), at 0.05 significance level, and the frequency of positives and the sample distribution were analyzed. To assess the concordance between IFD and bioassay, Kappa test was conducted separately for the bovine and the equine species. To evaluate the sensitivity and specificity of tests for both species, Screening Test of the above-mentioned software was performed.

\section{Results and discussion}

Of 643 brain samples from different municipalities in São Paulo State, 489 (76.05\%) were from cattle and 154 (23.95\%) from horses. Six results of bovine samples and three results of equine samples were discarded for presenting inconsistent data; thus, analyses included 483 samples from cattle and 151 samples from horses.

The years in which the number of received samples was larger were 2005, 2014 and 2015 (Figure 1), when transmission by the aerial cycle was shown to be greater although surveillance activities and rabies control in herbivores were constant throughout the years (Brasil, 2013; Póvoas et al., 2012).

Materials received for diagnosis are sent especially by technicians of the Animal Defense Offices/Agricultural Defense Coordination, agencies of the Secretariat of Agriculture and Supply of São Paulo State, as part of the State Program for Rabies Control in Herbivores, and by the Pathology Service of FMVZ-Unesp, Botucatu Campus, SP, Brazil, in cases of hospitalized animals suspected to have rabies. Currently, spongiform encephalopathy has been included in surveillance activities, 


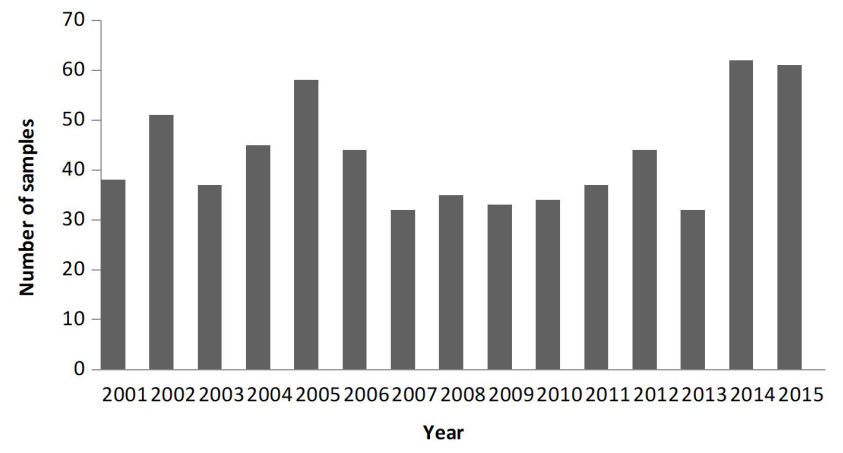

Figure 1. Brain samples received at the Zoonosis Diagnostic Service - SDZ, between 2001 and 2015, from cattle and horses.

and such differential diagnosis has been necessary for all cases negative for rabies using brain material from cattle (São Paulo, 2018).

Samples from cattle were more numerous due to the greater number of cattle farms, mostly with large herds, compared to those of horses, which are raised in farms or stud farms in this region. This disease is associated with the presence of the virus in the aerial cycle, the maintenance of Chiroptera in the nature and human economic activities. Therefore, such factors predispose rabies propagation in these species; the livestock growth increases the offer of food and artificial shelters, which facilitate the maintenance and perpetuation of populations of bats Desmodus rotundus, besides ecological changes, which favor Chiroptera migration in the search for new sources of food (Brasil, 2009; Kanitz et al., 2014).

Analyzing test results, FAT revealed 70 positive animals, of which 62 (88.58\%) were cattle and $8(11.42 \%)$ were horses; MIT indicated 85 positive animals, of which $68(80 \%)$ were cattle and 17 (20\%) were horses.

The gold standard tests recommended by WHO for rabies diagnosis are FAT and MIT since they yield reliable results and show 95-99\% sensitivity and specificity. Their advantages are low cost and possibility of isolating different viral strains from positive animals (Meslin \& Kaplan, 1996). The sensitivity and specificity of the tests in cattle and horses were calculated by considering diseased the animal that was positive according to the FAT. For cattle, sensitivity and specificity values of FAT were 88.24 and 99.52\%, respectively (Table 1), while for horses they were 47.06 and $100.00 \%$, respectively (Table 2). Peixoto et al. (2000) obtained FAT sensitivity of $76.6 \%$ for brain material from horses and 94\% for bovine cases.

The quality of diagnosis depends on some factors, especially the state of conservation of the brain material and, similarly important, the viral distribution in the examined brain fragments.

Viral replication in the lumbar region of the bone marrow leads to severe lesion in horses, which can die even before the virus reaches their central nervous system (Meyer et al., 1986). The viral load in brain fragments is essential for rabies diagnosis in horses since it varies according to the analyzed material or fragment, tending to be greater in tissue from brainstem, medulla and cerebellum. Thus, in the case of horses, rabies diagnosis should use material from the stem and the medulla (Silva et al., 1974).

According to Pedroso et al. (2010), the number of positive cases is great because samples are not sent to laboratory diagnosis and research about such a disease in this species is scarce (Lima et al., 2005).

Similarly, Costa et al. (2015) found conflicting results between these tests using brain material from the equine species. Concordance between FAT and MIT was excellent for both cattle (0.97) and horses (0.94). Separate evaluation of results indicated substantial concordance between FAT and MIT for horses (Kappa coefficient = 0.61) and excellent concordance for cattle (Kappa coefficient $=0.91$, evidencing greater sensitivity for the MIT.

Laboratory diagnosis is indispensible for the adoption of control measures and for the identification of rabies endemic regions (Kotait et al., 2008). Animals showing neurological symptoms should have their brain material sent to differential diagnosis of other encephalitis, 
Table 1. Comparison between the results of the fluorescent antibody test (IFD) and mouse inoculation test (PB) of equine and bovine brains SDZ from 2001 to 2015.

\begin{tabular}{cccc}
\hline \multirow{2}{*}{ IFD } & \multicolumn{2}{c}{ PB } & \multirow{2}{*}{ Total } \\
\cline { 2 - 3 } & Positives & Negatives & $70(11.01 \%)$ \\
Positives & $68(14.5 \%)$ & $2(0.31 \%)$ & $566(88.99 \%)$ \\
Negatives & $17(2.67 \%)$ & $549(86.32 \%)$ & \\
Total & $85(13.36 \%)$ & $551(86.64 \%)$ & \\
\hline
\end{tabular}

Kappa Coefficient (k): 0.86; McNemar Test $P=0.006$.

Table 2. Comparison between the results of the fluorescent antibody test (IFD) and mouse inoculation test (PB) in horses, SDZ from 2001 to 2015.

\begin{tabular}{cccc}
\hline \multirow{2}{*}{ IFD } & \multicolumn{2}{c}{ PB } & \multirow{2}{*}{ Total } \\
\cline { 2 - 3 } & Positives & Negatives & $8(5.23 \%)$ \\
\hline Positives & $8(5.23 \%)$ & 0 & $144(94.74 \%)$ \\
Negatives & $9(5.92 \%)$ & $135(88.82 \%)$ & \\
Total & $17(11.18 \%)$ & $135(88.82 \%)$ & \\
\hline
\end{tabular}

Kappa Coefficient (K): 0.61; McNemar Test $P=0.0027$.

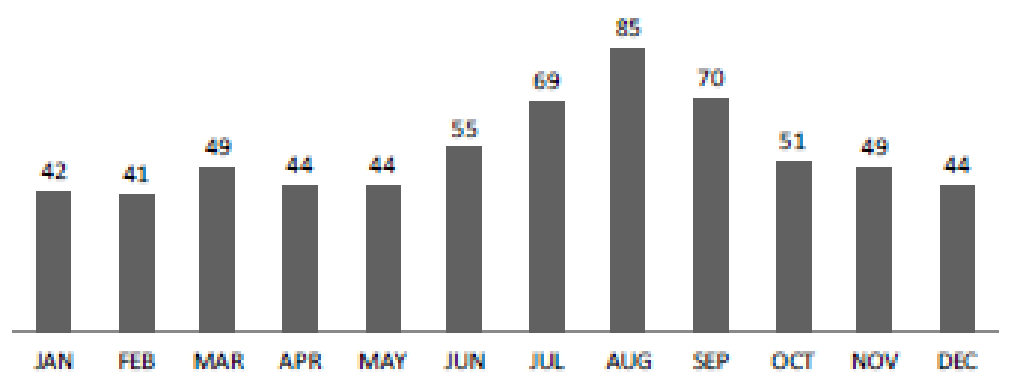

Figure 2. Monthly distribution of samples ( $N=643$ ) received from January 2001-2015 at the Zoonosis Diagnostic Service - SDZ - FMVZ - UNESP - Botucatu - Sao Paulo.

as well as to rabies diagnosis, since the disease confirmation can guide the adoption of control measures (Kotait et al., 1988). To reduce the cases of rabies in these species, hematophagous bat control is necessary, besides health educational activities and surveillance actions, such as yearly cattle and horse vaccination in endemic areas (Martins et al., 2015) to minimize economic losses and risks to the public health, especially for professionals developing activities with these animals.

As regards the monthly distribution of brain samples from both species received for diagnosis considering the period of this study, July, August and September concentrated the largest number of received samples: 69 in July, 85 in August and 70 in September, as shown in Figure 2.

Comparing the monthly frequency of positive animals, most cases of positive animals were concentrated in September (13), July (12) and May (9). Bats mate in the spring, when viral transmission may be greater among colonies and possibly to herbivores. In September, the number of received samples was large (70) and positivity was greatest (13 cases). Lima et al. (2005) found greater incidence of rabies between April and August.

\section{Conclusion}

Rabies occurrence in herbivores is variable according to the period of the year. The lower sensitivity of FAT in the equine species should be evaluated and could be improved if more brainstem and medulla material were sent for rabies diagnosis in this species. 


\section{References}

Ayres, M., Ayres Junior, M., Ayres, D. L., \& Santos, A. A. S. (2007). Bioestat 5.0: aplicações estatísticas nas áreas das ciências biológicas e médicas. Belém: IDSM.

Brasil, Ministério da Agricultura Pecuária e Abastecimento. (2009). Controle da raiva dos herbivoros: manual técnico. Brasília: MAPA.

Brasil, Ministério da Agricultura Pecuária e Abastecimento. (2013). Análise de indicadores epidemiológicos da raiva dos herbivoros no Brasil (2006 a 2012). Brasília: MAPA.

Costa, E. A., Rosa, R., Oliveira, T. S., Furtini, R., Fonseca Júnior, A. A., Paixão, T. A., \& Santos, R. L. (2015). Diagnóstico etiológico de enfermidades do sistema nervoso central de equinos no Estado de Minas Gerais, Brasil. Arquivo Brasileiro de Medicina Veterinária e Zootecnia, 2(2), 391-399. http://dx.doi.org/10.1590/1678-6765.

Dean, D. J., Abelseth, M. K., \& Atanasiu, P. (1996). The fluorescent antibody test. In F. X. Meslin, M. M. Kaplan \& H. Koprowski (Eds.), Laboratory techniques in rabies (4th ed., pp. 88-95). Geneva: WHO.

Kanitz, F. A., Kowalski, A. P., Batista, H. B. C. R., Carnieli Junior, P., Oliveira, R. N., Weiblen, R., \& Flores, E. F. (2014). Epidemiologia molecular de surto de raiva bovina na região central do Rio Grande do Sul. Ciência Rural, 44(5), 834-840. http://dx.doi.org/10.1590/S0103-84782014000500012.

Keane, D. P., \& Little, P. B. (1987). Equine vial encephalomyelitis in Canadá: a review of known and potential causes. The Canadian Veterinary Journal. La Revue Veterinaire Canadienne, 28(8), 497-504. PMid:17422841.

Koprowski, H. (1996). The mouse inoculation test. In F. X. Meslin, M. M. Kaplan \& H. Koprowski (Eds.), Laboratory techniques in rabies (4th ed., pp. 80-87). Geneva: WHO.

Kotait, I., Carrieri, L. M., \& Takaoka, Y. N. (2009). Raiva: aspectos gerais e clínica (Vol. 8). São Paulo: Instituto Pasteur.

Kotait, I., Gonçalves, C. A., Peres, N. F., Souza, M. C. A. M., \& Targueta, M. C. (1988). Controle da raiva dos herbívoros: manual técnico (Vol. 1). São Paulo: Instituto Pasteur.

Kotait, I., Ito, F. H., Carrieri, L. M., Souza, M. B. C. M., Perez, F. N., Ferar, I. F. J. J., Araujo, A. F., \& Gonçalves, N. L. V. (2008). Programa de Vigilância de Zoonoses e Manejo de Equídeos no Estado de São Paulo. Boletim Epidemiológico Paulista, 5(54), 1-9.

Lima, E. F., Riet-Correa, F., Castro, R. S., Gomes, A. A. B., \& Lima, F. S. (2005). Sinais clínicos, distribuição das lesões no sistema nervoso central e epidemiologia da raiva em herbívoros na região Nordeste do Brasil. Pesquisa Veterinária Brasileira, 25(4), 250-264. http://dx.doi.org/10.1590/S0100-736X2005000400011.

Martins, B. V., Oliveira, G. F., Dias, B. A. V. A., \& Moreira, C. W. (2015). Avaliação do Diagnóstico Laboratorial do Programa de Controle da Raiva Urbana no Rio de Janeiro, Brasil entre 2002-2011. Visa em Debate, 3(3): 56-63. DOI: http://dx.doi.org/10.3395/2317-269x.00245.

Meslin, F. X., \& Kaplan, M. M. (1996). An overview of laboratory techniques in the diagnosis and prevention of rabies and rabies research. In F. X. Meslin, M. M. Kaplan \& H. Koprowski (Eds.), Laboratory techniques in rabies (4th ed., pp. 80-87). Geneva: WHO.

Meyer, E. E., Morris, P. G., Elcock, L. H., \& Weil, J. (1986). Hindlimb hyperesthesia associated with rabies in two horses. Journal of the American Veterinary Medical Association, 188(6), 629-632. PMid:3957776.

Peixoto, P. M. Z., Cunha, S. M. E., Sacramento, V. R. D., Souza, M. A. C., Silva, Q. H. L., Germano, L. P., Kroeff, S. S., \& Kotait, I. (2000). Rabies Laboratory diagnosis: peculiar features of samples from equine origin. Brazilian Journal of Microbiology, 31(1), 72-75. http://dx.doi.org/10.1590/S1517-83822000000100017.

Pedroso, P. M. O., Colodel, E. M., Gomes, D. C., Varaschin, M. S., Bezerra Júnior, P. S., Barbosa, J. D., Tokarnia, C. H., \& Driemeier, D. (2010). Aspectos clínico-patológicos e imuno-histoquímicos de equídeos infectados pelo vírus da raiva. Pesquisa Veterinária Brasileira, 30(11), 909-914. http://dx.doi.org/10.1590/50100-736X2010001100002.

Póvoas, D. R., Chaves, N. P., Bezerra, D. C., Almeida, V. M., \& Saraiva, L. Q. (2012). Raiva em herbívoros no estado do Maranhão: um estudo retrospectivo. Revista Brasileira de Ciência Veterinária, 19(2), 86-89. http://dx.doi. org/10.4322/rbcv.2014.083.

Queiroz, L. H., Carvalho, C., Buso, D. S., Ferrari, C. I., \& Pedro, W. A. (2009). Perfil epidemiológico da raiva na região noroeste do estado de São Paulo no período de 1993 a 2007. Revista da Sociedade Brasileira de Medicina Tropical, 42(1), 9-14. http://dx.doi.org/10.1590/S0037-86822009000100003. PMid:19287928.

Robardet, E., Picard-Meyer, E., Andrieu, S., Servat, A., \& Cliquet, F. (2011). Intenational interlaboatoy trials on rabies diagnosis: an overview of results and variation in reference diagnosis techniques (fluorescent antibody test, rabies tissue culture infection test, mouse inoculation test) and molecular biology techniques. Journal of Virological Methods, 177(1), 15-25. http://dx.doi.org/10.1016/j.jviromet.2011.06.004. PMid:21703307.

São Paulo. Coordenadoria de Defesa Agropecuária do Estado de São Paulo. (2018). Programa Estadual de Controle da Raiva dos Herbívoros (PECRH). São Paulo. Retrieved in 2018, June 18, from https://www.defesa.agricultura. sp.gov.br/www/programas/?/sanidade-animal/programa-estadual-de-controle-da-raiva-dos-herbivoros/\&cod=39

Silva, A. R., Silva, M. N., \& Menezes, V. R. P. (1974). Ocorrência do vírus da raiva na medula e no bulbo de equinos na doença natural e sua ausência nas diferentes regiões do sistema nervoso central e outros tecidos. Pesquisa Agropecuária Brasileira, 9(7), 29-31.

Wada, M. Y., Rocha, S. M., \& Maia-Elkhoury, A. N. S. (2011). Situação da Raiva no Brasil, 2000 a 2009. Epidemiologia e Serviços de Saúde: Revista do Sistema Único de Saúde do Brasil, 20(4), 509-518. http://dx.doi.org/10.5123/ S1679-49742011000400010. 